\title{
ANALYSIS OF IMMIGRANT LABORS PENETRATION IN INDONESIA IN INDUSTRIAL SECTORS AND IMPACT ON THE EXISTENCE OF INDONESIAN LABORS- A STUDY OF SOCIAL POLARIZATION THROUGH THE THEORY OF INTEREST APPROACH
}

\author{
Abubakar Iskandar \\ State Administration Study Program Djuanda University, Bogor-16720, Negara, Indonesia.

\section{R. Akhmad Munjin} \\ State Administration Study Program Djuanda University, Bogor-16720, Negara, Indonesia

\section{Maria Fitriah} \\ Communication Science Study Program Djuanda University Bogor-16720, Negara, Indonesia

\section{Ike Atikah Ratnamulyani} \\ Communication Science Study Program Djuanda University Bogor-16720, Negara, Indonesia
}

\begin{abstract}
Law Number 13 on 2003 said the placement of workers was carried out without discrimination. Indonesian labors in PT Virtu Dragon Nickel Industri and PT Obsidian Stainless Steel from China, the remuneration is not appropriate because they work in the same type but they are paid differently. An immigrant labor paid 10 million rupiahs but an Indonesian labor paid 2.5 million rupiah in the same type of work. The objectives of this research are: (1) Explaining the consistency of Law Number 13; (2) Identifying an immigrant labor accompanied by 10 Indonesian labors to transfer of knowledge and transfer of jobs; (3) Describing the difference in salary of immigrant labors and Indonesian labors at the same type and level of work, (4) Knowing that immigrant labors working in Indonesia can speak Indonesian; (5) Disseminating the number of immigrant labors who have skill workers and unskillful workers; (6) Recording the number of and Indonesian labors dismissed from job. The approach used in this research is descriptive, correlational analytic. The sampling are 233 people. Data collection methods were interviews, FGDs and documentation. Data were analyzed through qualitative and quantitative analysis. The results showed 80.3 percent of immigrant labors had undergraduate education, and 44.4 percent of Indonesian labors had undergraduate education. The results showed 12.7 percent of immigrant labors had a high school education, while indonesian labors 30.9 percent. The results showed 6.4
\end{abstract}


percent of immigrant labors, and 66.5 of Indonesian labors could not speak a foreign language. On the other hand, immigrant labors who are able to speak foreign 14.2 percent and 12.9 percent Indonesian labors. The results showed that 24.5 percent of immigrant labors have skill workers and 34.3 percent of Indonesian labors have skill workers but 41.2 percent have unskillful workers.

Keywords: Law, Labor, Salary, Skills, Language, Education

Cite this Article: Abubakar Iskandar, R. Akhmad Munjin, Maria Fitriah and Ike Atikah Ratnamulyani, Analysis of Immigrant Labors Penetration in Indonesia in Industrial Sectors and Impact on the Existence of Indonesian Labors- A Study of Social Polarization Through the Theory of Interest Approach, International Journal of Management, 10 (6), 2019, pp. 346-362.

http://iaeme.com/Home/issue/IJM?Volume $=10 \&$ Issue $=6$

\section{INTRODUCTION}

\subsection{Background}

Labors placement are carried out without discrimination, but instead sacrificing Indonesian labors so that unemployment occurs 7.01 may not be reduced (BPS, 2017) [3]. Immigrants who work must have skills such as high-tech machinists, and others. An immigrant labor accompanied by 10 Indonesian labors to transfer of knowledge and transfer of jobs occurs. The problem of discrimination is the denial of the constitution and the potential to violate the 1945 Constitution (Iqbal, 2018) [12].

Migration has increased the density of immigrant labors to 85,974 people (Directorate of PPTKA, 2017) [3]. Based on PPTKA Kemenaker R.I data, it is said that the number of immigrant labors who entered Indonesia in 2018 are 353,630 people. (Menaker R.I, 2017). This density raises the periphery group and lower income distribution among them. With the increasing number of people working in Indonesia, the productivity of labors will increase so as to spur economic growth in Indonesia (Effendi Lubis, 2014) [8]. Please note that the industrial sector, it could be in the building / construction sector.

\subsection{Research Purposes}

Based on the background and subject matter, the research objectives are:

(1) Explaining the consistency of Law Number 13 on 2003 and Presidential Regulation Number 20 on 2018;

(2) Identifying an immigrant labor accompanied by 10 Indonesian labors to transfer of knowledge and transfer of jobs;

(3) Describing the difference in salary of immigrant labors and Indonesian labors at the same type and level of work,

(4) Knowing that immigrant labors working in Indonesia can speak Indonesian;

(5) Disseminating the number of immigrant labors who have skill workers and unskillful workers

(6) Recording the number of and Indonesian labors dismissed from job. 
Analysis of Immigrant Labors Penetration in Indonesia in Industrial Sectors and Impact on the

Existence of Indonesian Labors- A Study of Social Polarization Through the Theory of Interest Approach

\section{DATA USED AND PENETRATION OF IMMIGRANT LABORS}

\subsection{Research Sites}

The primary research sites were 11 foreign companies in the provinces of Southeast Sulawesi, East Java and Riau Islands that foreign companies and immigrant labors and Indonesian labors who work there, and the secondary location of the study was Immigration and the Department of Labor. Based on preliminary data this research can be carried out in foreign companies in the three provinces. Complete field data collection are for June 2019 - October 2019.

\subsection{Research Approach}

The approaches used in this research are descriptive, correlational analytic, and developmental.

\subsection{Population and Sample}

Population is a generalization area that consists of: objects / subjects that have certain qualities and characteristics determined by researchers to be studied and then drawn conclusions (Sugiyono, 2010) [13]. The population that is the object of this research are all immigrant labors or Indonesian Labors in foreign companies. To obtain a representative sample of each company, verification is carried out at least a day by researchers and research assistants through the following steps: (1) Data on composition of sample employees is based on citizenship status in the The Department of Labor., (2) Data from the Provincial the Department of Labor. compared with data from the Department of Labor District / City to check the truth of data from the Provincial Department of Labor and the Department of Labor Regency / City, (3) If there is a discrepancy between the data from the Provincial and Regency / City Department of Labor, the researcher and the research assistant directly check the data from the company, assuming that data from the Department of Labor District / City is also obtained from the Department of Labor Province, (4) Data from the Department of Labor Province is not just trusted, because it is then checked back data from the company compared with reports from each company, (5) Comparison of data from the Department of Labor Province with reports from each of these companies which are then intentionally taken and serve as a research sample, (6) If there is a match between the data from the Department of Labor Province and the Department of Labor Regency / City and reports from each company, the data will still be used. The results of employee sample collection by the Department of Labor province and the Department of Labor District / City and the results of verification can be seen in the table 1

The sampling techniques in this research are two or more phases:

a. Because this research is national in scope, the first population were 33 provinces in Indonesia

b. The first sample ( 3 provinces) were used as the second population, which consists of 3 provinces, they were Southeast Sulawesi, East Java and Riau Islands

c. The second population were taken by five cities / districts as samples, they were Kendari City, Konawe Regency, Surabaya City, Malang City and Batam City.

d. Then the second sample ( 5 cities / districts) was made as the third population. From this third population, 11 companies were distributed in the five cities / districts as the third sample.

e. The third sample (11 companies) was made as the fourth population, they were PT Yanagi, PT DSSP Power, PT Obsidian Stainless Steel, PT Virtu Dragon Nickel Industry, Spins Indonesia Prosperous Foundation, PT Sinar Mentari Gemilang, Wesley Foundation, Charis Foundation, PT Excelitas Technologies, PT Kemet Electronics Indonesia, and PT Ciba Vision

f. The fourth population was the fourth sample. The fourth sample was taken by immigrant labors and Indonesian labors that were 233 respondents, then recorded all the identities of 
selected respondents. This fourth element of the sample will be investigated as an element of research schematically the steps above according to (Palte, 1978) [10] are described as follows

Examples in this study are immigrant labors and indonesian labors who work in 11 Foreign Companies in Kendari City, Konawe Selatan District, Surabaya City, Malang City and Batam City. The five regencies / cities were chosen as research locations purposively based on the number of immigrant labors and Indonesian labors that exist in several categories of citizenship level according to data obtained at the Department of labor Provincial and Regency / City. Furthermore, each company was selected by several employees purposively taken from the results of the 2018 data collection. Each company was taken as sample employees by 20 samples distributed in 11 companies that were immigrant labors and Indonesian labors, so the total sample was 233 sample employees. Sampling is done proportionally (proportional stratified random sampling). The advantage of using this method was that (a) could represent all companies, (b) could compare one company with another company. The size of the samples taken from each company was not balanced, because each foreign company did vary quantitatively. Therefore, researchers determine for themselves how much percentage was taken to represent each company proportionally.

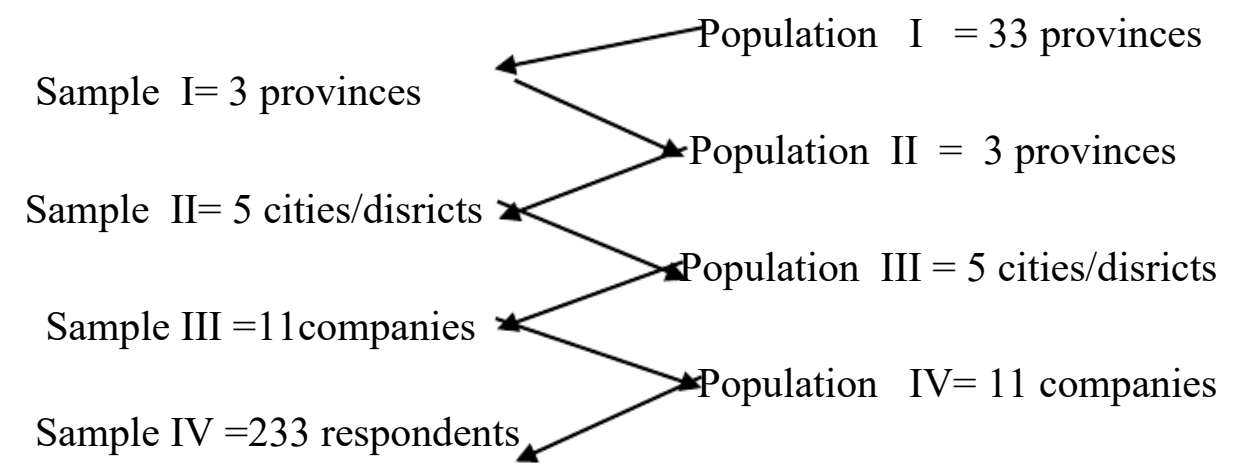

Based on the theory of sampling that if all possible random samples of size $n$ are taken without recovery from a finite population of size $\mathrm{N}$ which has a middle value and standard deviation, then the distribution of sampling for the mean sample mean will approach the normal distribution with the mean and standard deviation (Walpole, 1995) [17]. This proposition can approach the truth if the measurement results shown by the independent variables approach normal. The importance of this proposition is mainly to make conclusions about the estimator of the sample which according to the central proposition follows or approaches normal functions, if the sample is large enough if $\mathrm{n}$ goes to infinity. This proposition in practice already applies if $n>30$, because in this situation the value of the Table $t$ for a particular alpha will be close to the value of a normal table (Supranto, 2000) [15]. Based on table 2 above, samples can be arranged as follows

\subsection{Types of Data and Collected Data}

This study are primary data and secondary data. Primary data is taken directly from the respondent, while secondary data is taken from other relevant agencies. Whereas the data is collected through:

\subsubsection{Interview}

Interview based on a questionnaire. Questionnaire is a data collection technique that is done by giving a set of questions or written statements to respondents to answer. Questionnaire is an efficient data collection technique if the researcher knows with certainty the variables to be measured and knows what can be expected from respondents (Sugiyono, 2010) [13]. 
Analysis of Immigrant Labors Penetration in Indonesia in Industrial Sectors and Impact on the

Existence of Indonesian Labors- A Study of Social Polarization Through the Theory of Interest

\subsubsection{Observations}

Approach

According to (Ritzer, 992) [11] said that the observations made were mainly to understand the intersubjective and intrasubjective realities of social actions and interactions. The lightest technique is observation that is exploratory. This technique is most subjective in nature and its use is closely related to the actual observation plan. Observation techniques are usually used primarily to observe the actual behavior, and objects that can be seen and touched, For example, observation of the products are produced by a company, observation of company facilities and infrastructure, schools and other services.

\subsubsection{Documentation}

Documentation is looking for data about things or variables that are records of events that have passed, documents are usually in the form of writing, drawings, sketches, and others. Data collection techniques as a complement to observation techniques. The documentation method used by researchers is to collect data through specific records, both soft and hard copy, photo shoots from FGD forums, photos of company facilities and infrastructure, interviews with resource persons and etc.

\subsubsection{Focus Group Discussion (FGD)}

Focus Group Discussion (FGD), is a focused discussion forum involving stakeholders to obtain input, opinions, suggestions, and questions concerning immigrant labors and Indonesian labors in foreign companies. In the FGD it is expected to obtain input in the form of models and strategies to manage immigrant labors and Indonesian labors in foreign companies in order to obtain the commitment of accountable, transparent, objective and fair company owners.

\subsubsection{Participation}

Participation is the participation of stakeholders in helping data collection in a number of foreign companies in 11 companies. This participation is very important considering the formal relationship between the Department of labor and foreign companies is supervisory so that data that is difficult to achieve, can be obtained through supervisors of foreign companies and acts as a guide to get the right and correct data.

\subsubsection{Data Analysis}

Data was analyzed through qualitative and quantitative. Qualitative data used content analysis, and quantitative data through Produce Moment Correlation.

\section{RESULTS AND DISCUSSION}

\subsection{Implementation of Law Number 13 of 2003 and Presidential Regulation Number 20 of 2018}

In (Chapter VIII, article 42 of Law Number 13 of 2003) [16] concerning the use of immigrant labor says that (1) every employer who immigrant labors are required to have written permission from the minister or appointed official, (2) Employers of individuals are prohibited from employing immigrant labors, (3) Obligations to have a permit as referred to in paragraph 1 do not apply to representatives of foreign countries that use foreign workers as diplomatic and consular employees, (4) immigrant labors work can be employed in Indonesia only in a work relationship for a certain position and certain time, (5) Provisions regarding certain positions and certain times as referred to in paragraph 4 are stipulated by ministerial decree, (6) immigrant labors as referred to in paragraph 4 whose term his work runs out and cannot be replaced can be replaced by other immigrant labor. 
This was confirmed through (Presidential Regulation Number 20 Year 2018) [9] concerning the Use of immigrant labors. This regulation was issued with the consideration that in order to support the national economy and expand employment opportunities through increased investment, the government deemed it necessary to re-regulate permits for the use of foreign workers and on the basis of these considerations on March 26, 2018 President Joko Widodo had signed Presidential Regulation Number 20 of 2018 about the use of immigrant labors.

In the Presidential Regulation it is mentioned that the use of immigrant labors is done by immigrant labors in relation to work for certain positions and certain time which is done by taking into account the conditions of the domestic labor market. Every immigrant labors according to Presidential Regulation must prioritize the use of Indonesian workers in all types of positions available. In the event that the position referred to cannot be occupied by Indonesian labors, the position may be occupied by immigrant labors, and immigrant labors are prohibited from occupying a position in charge of personnel and / or certain positions stipulated by the Minister in accordance with the provisions of article 4 paragraph 1 and 2 of the Presidential Regulation.

Affirmed in the Presidential Regulation, every employer who uses immigrant labors must have a RPTKA (Immigrant Labors Use Plan) which is approved by the Minister or appointed official and at least contains (1) reasons for the use of immigrant labors, (2) Position and / or position of immigrant labors in the organizational structure of the company, (3) the period of time for using of immigrant labors, and (4) the appointment of Indonesian labors as companions of immigrant labors.

Employer who uses immigrant labors are not required to have a RPTKA to employ an immigrant labors who is (1) a shareholder who serves as a member of the Board of Directors or a Board of Commissioners to an immigrant labors employer, (2) Diplomatic and consular employees to representatives of foreign countries, or (3) immigrant labors in the type of work required by the government, reads article 10 paragraph 1 of this regulation. For emergency and urgent work, according to the Presidential Regulation, employers can hire immigrant labors by submitting a request for approval of the RPTKA to the Minister or an appointed official no later than 2 working days after immigrant labors works. Furthermore, ratification of the RPTKA will be given no later than 1 working day after the application has been received in full.

It is emphasized in the Presidential Regulation that employers who will employ immigrant labors convey the data of prospective immigrant labors to the Minister or appointed official which includes: (1) name, gender, place and date of birth, (2) citizenship, (3) passport number, period valid passport and passport where issued, (3) name, position, and a certain period of time, (4) guarantee statement and immigrant labors employer, and (5) education certificate and certificate of work experience or certification of competence in accordance with the conditions of office to be occupied immigrant labors.

The minister or designated official shall submit notification of receipt of data of prospective immigrant labors as referred to the employer is not later than 2 working days with a copy of the Directorate General of Immigration, reads article 14 paragraph 3 of the Presidential Regulation. According to this regulation the employer is required to pay compensation funds for the use of immigrant labors who are employed after receiving notification and made through a bank appointed by the Minister who is a non-tax state revenue. Payment of compensation funds for the use of immigrant labors and the obligation to have this RPTKA is not required for government agencies, representatives of foreign countries, and international bodies that employ immigrant labors. 
Analysis of Immigrant Labors Penetration in Indonesia in Industrial Sectors and Impact on the

Existence of Indonesian Labors- A Study of Social Polarization Through the Theory of Interest Approach

\subsection{Socio-Economic Characteristics Example}

\subsubsection{Education}

Education according to the view of the Progressivism school is part of the general socialpolitical revormis movement that marks American life. Progressivism as a theory that emerged in reaction to traditional education that emphasized formal methods of teaching, mental learning and, the classical atmosphere of western civilization. Basically the theory emphasizes several principles, among others; first, the educational process begins and ends in children. Second, students are active subjects rather than passive. Third, the teacher's role is only as a facilitator, guide or director. Fourth, schools must be cooperative and democratic. Fifth, activities are more focused on problem solving, not for teaching study material.

That is why curriculum according to the flow of progressivism as the heart of education is not only interpreted as a part of the range of subjects offered in a school program, but the curriculum has a broader meaning. Therefore, many experts interpret the curriculum with different pressure points. For example, Hirts and Petters emphasize the functional aspects, ie the curriculum is positioned as a reference in the teaching-learning process. Musgave emphasizes the scope of learning experiences which include experiences outside and inside the school. Where the activities and experiences of students are in the control of educational institutions.

The progressivism sees the curriculum as an educational experience, it is experimental in nature, and there are plans and regular arrangements. Learning experience is any experience that is compatible with the objectives according to the principles outlined in education, where every learning process that exists helps the growth and development of students. The Progressivism is student-centered education and places greater emphasis on creativity, activity, "naturalistic" learning, "real world" learning outcomes, and also peer experience. Dewey's theory of school is "Progressivism" which emphasizes more on students and their interests than on the subject itself. Then comes what is called "child centered curriculum" and "child centered school".

The progressivism prepares children today compared to an uncertain future, as Dewey revealed in his book "my pedagogical creed", that education is a process of life and not preparation for the future. So Dewey's idea application is that many children participate in physical activities first, then specialization.

Education in the job market gets a very high place and position, because through education people can gain knowledge, and with knowledge people can compete in the job market. The presence of immigrant labors and Indonesian labors in any foreign company will be empty if not accompanied by knowledge. Likewise, the level of someone's immigrant labors and Indonesian labors will be determined by the quality of one's knowledge. Because science is very decisive, education, as a process of acquisition of knowledge, becomes very important. Therefore, the process of seeking knowledge must be continuously carried out, wherever and whenever.

The quality of human resources like this will determine the degrees of excellence (degrees of reliability) of immigrant labors and Indonesian labors. The quality of human resources can thus be defined as a combination of the characteristics of all available resources within immigrant labors and Indonesian labors, including the characteristics of reason (intelligence) that determine the degree of reliability of a workforce both foreign and Indonesian. The results showed that as many as 80.3 percent of the level of immigrant labors graduated, while 44.4 percent of Indonesian labors also had a university degree. Then following the labors who graduated from high school. 
The results showed that 12.7 percent of immigrant labors who had high school education, while Indonesian labors who had high school education were 30.9 percent. Complete can be seen in table 3

\subsubsection{Immigrant Labors assistance for Transfer of Knowledge and Job}

According to (Andrie Indriawaty, 2012) [1] on the issue of Immigrant Labors Assistance for the Transfer of Knowledge and Job can be explained several important elements as follows:

\subsubsection{The concept of Assistance}

According to (Andrie Indriawaty, 2012) [1] said that mentoring is a strategy that really determines the success of the company's programs. In the context of empowering immigrant labors and Indonesian labors, the role of experts is manifested in their capacity as a companion, and not as a problem solver. So, in this case the active participation of experts is needed. In empowering immigrant labors and Indonesian labors, there is a process and social action. The process does not emerge automatically, but grows and develops based on interactions between foreign companies and local government change agents. For example in the foreign language handling program, immigrant labors are a group that is incapable of speaking English and Indonesian, then to empower them change agents are present as a companion to activities in the foreign company. So, conceptually mentoring immigrant labors and Indonesian labors are a dynamic interaction between immigrant labors and Indonesian labors who cannot speak foreign languages.

\subsubsection{Purpose of Assistance}

- Increase the capacity of immigrant labors and Indonesian labors to operate foreign company programs and utilize their knowledge to serve the needs of immigrant labors and Indonesian labors to improve their knowledge and skills.

- Increase the capacity of immigrant labors and Indonesian labors to manage both the administration and technical aspects of a program.

- Increase the capacity of immigrant labors and Indonesian labors to overcome problems that occur.

- Increase the capacity of immigrant labors and Indonesian labors in a program for advancement and foreign companies.

\subsubsection{Assistance Strategy}

\section{Approach}

- A rational approach in achieving program objectives is development based on immigrant labors and Indonesian labors or the community as a program target to harmonize program planning, implementation and control.

- Positioning immigrant labors and Indonesian labors as the main actors in these foreign companies.

- Prioritizing universal values in the development process of these foreign companies

- Using immigrant labors and Indonesian labors empowerment approaches according to company characteristics.

\section{Strategy}

- Intensifying efforts to immigrant labors and Indonesian labors to increase their ability and independence

- Establish partnerships to realize empowerment and independence. 
Analysis of Immigrant Labors Penetration in Indonesia in Industrial Sectors and Impact on the

Existence of Indonesian Labors- A Study of Social Polarization Through the Theory of Interest

Approach

- Optimizing all resources: companies, immigrant labors and Indonesian labors, synergistically.

- Developing accountable corporate institutions.

- Improve the ability of learning in understanding their needs and potential and solving their various problems.

\section{Objects}

The objects of assistance are immigrant labors and Indonesian labors who are unable to be accompanied.

\section{Assistance Tasks}

- Coordination with related stakeholders in mentoring

- Following the debriefing

- Coordination and socialization with the government in the context of implementing empowerment and assistance programs.

- Conduct focused discussions in order to determine the selected companies as targets in supporting the implementation of empowerment and assistance programs.

- Coordinate with the government to prepare work plans for implementing the empowerment and assistance programs.

- Conduct training and mentoring

- Carry out participatory debriefing for immigrant labors and Indonesian labors to support the programs.

- Prepare work reports.

\section{Assistance Strategy in Increasing the Capacity of immigrant labors and Indonesian labors}

- Identify the needs for increasing the capacity of immigrant labors and Indonesian labors. And determine resources.

- An assessment of the needs for enhancing the capacity of immigrant labors and Indonesian labors are conducted. By assessing the conditions and contextual issues which are considered as potential and limiting implementation of Capacity Building for Foreign immigrant labors and Indonesian labors.

- Together with stakeholders identifying participants in the Capacity Building for immigrant labors and Indonesian labors? For this reason it is necessary to consider continuity in participating in the Capacity Building for immigrant labors and Indonesian labors. And confirmed by an assignment decree on staff to take part in the immigrant labors and Indonesian labors Capacity Building project until completion).

- Determine the parties that can be invited to work together in technology and industry. Their attitudes, knowledge and skills need to be identified

\section{Implementation}

Implementation of Capacity Building immigrant labors and Indonesian labors consists of the following activities:

- Accompany Report Making

- Accompany reports on Improvements 
- Assists program planning and implementation

\section{Assistance Program Process}

- Counseling training

- Coordinate with stakeholders to explain the programs that exist in the company

- Together with stakeholders determine the location of the training and ensure the suitability of the facilities / infrastructures

- Together with stakeholders design a training schedule

- Together with Stakeholders carry out the Counterpart Training

- Together with the Stakeholders prepare a mentoring work plans

- Prepare reports on the implementation of training activities and training financial accountability.

- Implementation of Empowerment Assistance

- Inventory the existing problems in the field

- Inventory ways to overcome problems (solutions) that have been carried out by the facilitator.

- Analyze existing problems, then find effective alternative solutions.

- Arranging Work Assistance Programs for Empower immigrant labors and Indonesian labors.

\section{Reporting}

- Prepare and report the results of evaluation monitoring

- The format of the monitoring and evaluation report contains the companion's identity, monitoring date, name and address.

- The contents of reporting are planning and indicators of success

- Weekly report

- Monthly report

- Annual Report (Complete)

The ratio of assistance for an immigrant labors is supported by a number of Indonesian labors as illustrated in the table 4.

\subsubsection{Payroll System}

In general, the amount of salary earned by Immigrant labors and indonesian labors in 11 companies under study, is very closed, not disclosed openly, except companies from Japan. It is PT Yanagi Histalaraya. A labor who hold positions is given salary standards as in the table below. The reasons why the companies are very closed in telling the true salary of immigrant labors and indonesian labors include: (1) it is feared that immigrant labors and indonesian labors who have expertise will leave the company and move to a new company that is paid more, (2) avoid the income tax that is imposed on immigrant labors and indonesian labors concerned, while their salaries are not too high. The details can be seen in the table 5 .

\subsubsection{Foreign Language Mastery}

The results showed that in general 6.4 percent of Immigrant labors could not speak foreign languages, and Indonesian labors were 66.5 percent could not speak foreign languages. On the other hand, Immigrant labors who were able to speak foreign languages were 14.2 percent, and 
Analysis of Immigrant Labors Penetration in Indonesia in Industrial Sectors and Impact on the

Existence of Indonesian Labors- A Study of Social Polarization Through the Theory of Interest Approach

Indonesian labors were 12.9 percent. It should be noted that in general Immigrant labors and Indonesian labors working in Chinese companies on average could not speak foreign languages both English and Indonesian and Mandarin, thus making communication difficult between Immigrant labors and Indonesian labors in the context of the transfer of knowledge and jobs.

Communication between Immigrant labors and Indonesian labors in a foreign company seeks to build more clearly in revealing various problems in the company concerned. The communication that is built is interpersonal communication in a corporate environment. This communication structure will cause a strong anticipation to the company's needs going forward. The communication structure referred to is the communication network between Immigrant labors and Indonesian labors in maintaining the closeness and connectedness between subsystems in the company system so that the process of reaching agreement on the planned needs becomes real (Iskandar, 2012) [5]

The type of communication relationship analysis used to find out the communication relationships within a company is the communication of several individuals who converge into one system unit. Communication relationships at the system level, two indices used as structural variables are system connectedness and system openness.

System connectivity is the degree of members (degrees of Immigrant labors and Indonesian labors) in a company system that is related to each other which can be calculated from the amount of interpersonal information flow available, while the openness of the system is the degree at which Immigrant labors and Indonesian labors of a system exchange information with outside systems.

The communication connectedness index can be calculated in both systems, therefore Immigrant labors and Indonesian labors in the company system become units of analysis (Setiawan and Muntaha, 2000) [14]. Figure 1 shows internal and external communication both in the company as in the picture

The picture above shows the system of interactions that occur in various statements consisting of six types of interaction both Immigrant labors and Indonesian labors, Immigrant labors and Chairman, Indonesian labors and Leaders, Immigrant labors and Indonesian labors with external and Chairman with other external, so they can misunderstanding and decision making at the company level is less precise. Analysis of the structure of interaction between Immigrant labors and Indonesian labors seeks to reveal the intensity of interaction (degree of interaction) between individuals within the company and between workers and external. A deep understanding of the interaction structure analyzed will be useful when responding to the objectives to be achieved and the decision making that will be carried out by the company.

Figure 1 shows that there is a connection between Immigrant labors and Indonesian labors, while on the other hand there is openness of Immigrant labors and Indonesian labors that is between immigrant labors, indonesian labors and Company chairman with external. To find out the degree of communication connectedness between Immigrant labors and Indonesian labors, as well as company chairman with other parties, two statements (can be foreign and not foreign language) are included in the questions involved in communication to find out which statement is the most intense among them. Complete can be seen in table 6.

\subsubsection{The Ownership of Skill Workers and Unskill Workers}

The results showed that 24.5 percent of Immigrant labors had Skill Workers and 0.0 percent did not have Unskill Workers, while 34.3 percent of Indonesian labors had skill workers and 41.2 percent had Unskill Workers. These data show that Immigrant labors are superior when compared to Indonesian labors. Speaking about Skill Workers and Unskill Workers, of course we are talking about educational models and curriculum content, so that Indonesian labors have comparative and competitive advantages, plus curricula that are anticipatory, adaptive and 
applicative, and ultimately Indonesian labors who have a reputation and special qualities. Sociologically, human characteristics Indonesia is divided into two categories, they are: The first type is The Hunter of Certificate, and the second type is The Hunter of Science.

The First Type, is "The Hunter of Certificate". As a result, then do not have adequate knowledge because their campus is "Monumental". They cannot able to elevate themselves as pragmatic and ideological human beings who then they cannot be used as normative references, or can be emulated. The success of development which is measured through prosperity through the development of the potential of science and technology is not a commitment of many children in Indonesia country.

It is inevitable that in an atmosphere of development that is pragmatic and ideologic in mind and which is oriented to the interests of production for the welfare of the people in order to ensure constant economic growth, the quality of this generation is less visible as a productive human being. Departing from people who are production centered, the meaning of Indonesian labors resource becomes very limited that in its capacity as one of the factors of production. The Indonesian labors are involution (not developing) as children who do not crave the realization of a whole personality through learning activities through reading, writing, listening, discussion and research, but they are not more than human beings who favor at business centers or commercial stranger.

In this situation and intellectual development, Indonesian labors will soon be subordinated and degraded. For example, being a labor or cleaning service for foreign companies. Quality Indonesian labors should not have to be subordinated to a foreign company system. Indonesian labors and their mission of education are conceived as such, clearly reducing the meaning of Indonesian labors in qualities that have been dehumanized too far. Here our Indonesian labors are often powerless to prevent the system of foreign companies because in this system Indonesian labors who have a noble duty always loses and gives up. Therefore, one of the Indonesian labors capacity development is through special and reputable universities.

There are already many human resources in Indonesia country, but there are also many human resources that have experienced degradation and deprofessionalisation, then the role of Human Resource to instill and grow empowerment, so they can participate in life on the basis of the principles of freedom (voluntarism) and not limited to the principle of knowledge for sale (selling cheap knowledge) then becomes dwarfed and dimmed. The Human Resource no longer interpreted as "Brand Image" which must be freed from various attachments that tether and support, but dare to get out of pressure, so there is no dependency on business centers and commercial centers owned by foreigners both those who need money or the market or who bureaucratic or the state interest.

Humans who lead to certificate ownership as a sign of graduating a school without being buried with adequate knowledge, will soon be invaded by human resources in USA, Europe, Japan and China, which have many companies in Indonesia, which are more called are figures with creative and critical personalities, full of initiative, and full of moral courage to present alternative policies. In a pragmatic and idealistic development, the Indonesian human resources of the mujtahid type will certainly meet the demands of the times rather than the human resources of the type of followers. A mujtahid has great ability and empowerment, while human resources followers type who are human resources who will not be able to do anything unless mobilized obediently into controlled activities, according to the central scenario under the authority of entrepreneurs or conglomerates of China, the US, Japan, Europe and even Jews.

Second type: "knowledge hunters", are people who want to develop, want to progress, have ideals and want to be scientists. Motivation, self-reconstructing, self-restructuring and selfrepositioning through reading writing, listening research, and discussion on all issues so as not 
Analysis of Immigrant Labors Penetration in Indonesia in Industrial Sectors and Impact on the

Existence of Indonesian Labors- A Study of Social Polarization Through the Theory of Interest Approach

to slip into the zone of degradation and deprofessionalisation. That is why reputable and special education is so important for all of our children to progress.

That is why the curriculum as the heart of education is not only interpreted as a set of subjects offered in a school program, but the curriculum has a broader meaning. Therefore, many experts interpret the curriculum with different pressure points. For example, Hirts and Petters emphasize the functional aspects. The curriculum is positioned as a reference in the teaching and learning process. While Musgave emphasizes the scope of learning experiences that include experiences outside and inside the school, where the activities and experiences of students are in the control of educational institutions.

This domestic education gained a very high place and position, because through education one can gain knowledge, and with knowledge people know their Lord, faith to their God. A person's worship will also be empty if not accompanied by knowledge. Likewise, the level of one's degree, besides faith, is also determined by the quality of one's knowledge (wisdom). Because science is very decisive, education, as a process of acquisition of knowledge, becomes very important. Therefore, the process of seeking knowledge must be continuously carried out, wherever and whenever, meaning that knowledge is sought from beginning to end or from birth to death (Asmil, 2010) [2] Completely seen in table 7

\subsubsection{Dismissed Works of Immigrant Labors in Foreign Companies}

The results showed that neither Immigrant Labors nor Indonesian labors were dismissed works at a number of foreign companies in 11 foreign companies in Indonesia. Indonesian labors who are unable to be provided with skills training except those who violate applicable regulations in the company, for example are dishonest, lazy and corrupt. As for Immigrant Labors, especially Chinese Immigrant Labors, they will be dismissed from foreign companies that they work if they have finished their contract work period for six months, the same conditions are also treated for Indonesian labors if the work contract has been completed, and depends on the owner of the company whether re-recruited or no. Therefore, the issue that says that Chinese immigrant labors are overwhelming in Indonesia is not true, because every six months there is always a change of Chinese immigrant labors to work in Indonesia, so that we can find a number of Chinese immigrant labors in a number of airports in Indonesia. Because there is a circulation of Chinese immigrant labors who come to replace Chinese immigrant labors who have finished their work contracts and immigrant labors who have finished their work contracts back to China, and indeed it always happens to meet immigrant labors who come and immigrant labors who return and look so many Chinese foreign immigrant labors at the airport or on the plane. Complete can be seen in table 8 .

\subsubsection{Penetration of Immigrant labors in Foreign Companies and Their Impacts on the Existence of Indonesian labors}

Penetration of Immigrant labors in Foreign Companies and Their Impact on the Existence of Migrant Workers used Product Moment Correlation (Pearson) analysis. Product Moment Correlation (Pearson) is a correlation analysis for parametric statistics. The analysis can be explained below.

\subsubsection{Interpretation}

The correlation coefficient between foreign language masters and country of origin is $.816 * *$ meaning that the relationship between mastery of foreign languages and country of origin is very close. The correlation coefficient is positive $(+)$, meaning that the relationship between the origin of the country and the mastery of a foreign language is in the same direction so that if the foreign worker is brought in from a foreign country, the mastery of a foreign language is 
better. The sign $* *$ indicates that the correlation coefficient is significant at 99 percent confidence level.

The correlation coefficient between worker skills and country of origin is $-.472 * *$, meaning that the relationship between skills workers and the nation's nose is very close. The correlation coefficient is positive $(+)$, meaning that the relationship between the origin of the country and the skills of workers is in the same direction so that if the foreign worker is brought in from a foreign country, the skill of workers will be better. The sign ** indicates that the correlation coefficient is significant at 99 percent confidence level.

The correlation coefficient between workers 'skills and foreign language mastery is -.410 **, meaning that the relationship between workers' skills and foreign language mastery is very close. The correlation coefficient is positive $(+)$, meaning that the relationship of mastery of foreign languages with the skills of workers is in the same direction so that if foreign or Indonesian workers master foreign languages, the skills of workers will be better. The sign ** indicates that the correlation coefficient is significant at 99 percent confidence level.

The correlation coefficient between the skills of workers and the transfer of knowledge and transfer of jobs from foreign workers to Indonesian workers is $.310^{* *}$, meaning that the relationship between the skills of workers and the transfer of knowledge and transfer of jobs is very close. The correlation coefficient is positive $(+)$, meaning that the relationship of workers' skills with the transfer of knowledge and transfer of jobs in the same direction so that if there is a transfer of knowledge and transfer of jobs in Indonesian workers, the skills of workers are getting better. The sign $* *$ indicates that the correlation coefficient is significant at 99 percent confidence level.

The correlation coefficient between worker skills and scientific competence is -.162*, meaning that the relationship between worker skills and scientific competence is quite close. The correlation coefficient has a positive sign $(+)$, meaning that the relationship of workers' skills with scientific competency is unidirectional so that if scientific competence can be applied properly, the skills of workers will be better. The * sign indicates that the correlation coefficient is significant at 95 percent confidence level 
Analysis of Immigrant Labors Penetration in Indonesia in Industrial Sectors and Impact on the

Existence of Indonesian Labors- A Study of Social Polarization Through the Theory of Interest Approach

Correlations

\begin{tabular}{|c|c|c|c|c|c|c|}
\hline & & Country & Language & skill & $\begin{array}{c}\text { Knowledge } \\
\text { Transfer }\end{array}$ & Competencie \\
\hline \multirow[t]{3}{*}{ Country } & & 1 & $.816^{* *}$ & $\begin{array}{c}- \\
.472^{* *}\end{array}$ & .027 & .060 \\
\hline & Sig. (2-tailed) & & .000 & .000 & .736 & .452 \\
\hline & $\mathrm{N}$ & 233 & 232 & 161 & 161 & 161 \\
\hline \multirow[t]{3}{*}{ Language } & Pearson Correlation & $.816^{* *}$ & 1 & - & .004 & .056 \\
\hline & Sig. (2-tailed) & .000 & & .000 & .960 & .477 \\
\hline & $\mathrm{N}$ & 232 & 232 & 161 & 161 & 161 \\
\hline \multirow[t]{3}{*}{ Skill } & Pearson Correlation & $-.472^{* *}$ & $-.410^{* *}$ & 1 & $.310^{* *}$ & $-.162^{*}$ \\
\hline & Sig. (2-tailed) & .000 & . 000 & & .000 & .040 \\
\hline & $\mathrm{N}$ & 161 & 161 & 161 & 161 & 161 \\
\hline \multirow{3}{*}{$\begin{array}{l}\text { Knowledge } \\
\text { Transfer }\end{array}$} & Pearson Correlation & .027 & .004 & $.310^{* *}$ & 1 & -.075 \\
\hline & Sig. (2-tailed) & .736 & 960 & .000 & & .347 \\
\hline & $\mathrm{N}$ & 161 & 161 & 161 & 161 & 161 \\
\hline \multirow[t]{3}{*}{ Competencie } & Pearson Correlation & .060 & .056 & $-.162^{*}$ & -.075 & 1 \\
\hline & Sig. (2-tailed) & .452 & .477 & .040 & .347 & \\
\hline & $\mathrm{N}$ & 161 & 161 & 161 & 161 & 161 \\
\hline
\end{tabular}

**. Correlation is significant at the 0.01 level (2-tailed).

*. Correlation is significant at the 0.05 level (2-tailed).

\section{CONCLUSION}

The conclusion that can be drawn from this study is that there is no consistency of Law Number 13 of 2003 with Presidential Regulation Number 20 of 2018 because an expert immigrant labor has not been accompanied by local workers optimally. In addition, foreign workers, especially Chinese labors who work in Indonesia, on average do not speak Indonesian and the payroll system is different. The correlation between foreign language rulers and country of origin is $.816^{* *}$ meaning that the relationship between mastery of foreign languages and national nasals is very close so that if foreign workers are brought in from foreign countries the better mastery of foreign languages. The correlation coefficient between worker skills and country of origin is $-.472 * *$, meaning that the relationship between skills workers and the nation's nose is very close, so that if the foreign worker is brought in from an outside country, the skill of workers will be better. The correlation coefficient between the skills of workers and mastery of foreign languages is $-.410^{* *}$, meaning that the relationship between skill workers and mastery of foreign languages is very close, so that if foreign or Indonesian workers master a foreign language, the skills of workers will be better. The correlation coefficient between the skills of workers and the transfer of knowledge and transfer of jobs from foreign workers to Indonesian workers is $.310^{* *}$, meaning that the relationship between the skills of workers and the transfer of knowledge and transfer of jobs is very close, so if there is a transfer of knowledge and transfer of jobs job for Indonesian workers, the skill of workers is getting better. The correlation coefficient between skill workers with scientific competence is $-.162 *$, meaning that the relationship between skill workers and scientific competence is quite close, so that if scientific competence can be applied well the workers' skills will be better. 


\section{ACKNOWLEDGEMENTS}

This gratitude is conveyed to the Chancellor of Juanda University, Bogor, because for his authority, gave us the opportunity to act as a lecturer to prepare a research proposal and submit it to the Directorate of Research and Community Service at the Directorate General of Research and Development Strengthening, and after being evaluated, this proposal was deemed appropriate for research. Therefore, the authors would like to thank the Directorate of Research and Community Service of the Directorate General of Strengthening Research and Development of the Ministry of Research, Technology and Higher Education. Thanks are also extended to the Governors of the Provinces of Southeast Sulawesi, East Java and Riau Islands who have given research permits in their regions. A thank you was also conveyed to the Head of the Department of labor of each Province, both at the Provincial, City and Regency level, so that interviews, observations and FGDs can run smoothly and successfully. Thank you also goes to the owners of the companies who had given us the opportunity to conduct research at their companies.

\section{REFERENCES}

[1] Andrie Indriawaty, Community Development. Buana Surya Primatama, 2012, pp. 47

[2] Asmil Ilyas, Principles of Islamic Religious Teachings and Worship Implementation Guidelines for TNI Members and Their Families. Army Mental Development Office. Jakarta, 2010

[3] Statistics Indonesia, About the Amount of Unemployment in Indonesia. https://tirto.id/bpscall-the-number-unemployment-in Indonesia-reach 7.01 million people, 2017

[4] Directorate of PPTKA,Foreign Workers Working in Indonesia., 2018

[5] Iskandar, A. New Paradigm Benchmarking Poverty. A Study on the Use of Single Indicators. Issuer of a Limited Liability Company Bogor Agricultural Institute Press. Bogor, 2012, pp 4

[6] Minister of labor R.I, Minister of labor Opens Foreign Workers Data at R.I.https: //finance.detik.com/berita-ekonomi-bisnis/d-3990690/menaker, 2018

[7] National Family Planning Coordinating Board. Opinion of Prosperous Family Development Jakarta. Indonesia, 1998, pp 11

[8] Otra Ayu Basica Effendy Lubis. Effect of Total Labor Force, Education Level and Education Expenditures on Economic Growth. Journal of Economics 2014, Vol 10, No.2

[9] Regulation of President R. I. No. 20 of 2018 concerning the use of foreign workers

[10] Palte J.G.L. Social Economic Research Method (Especially Survey) Stencil Lecture Note, 1978, pp 120

[11] Gehan Mohamed Ahmed Mostafa, Afaf Salah Abd-El-Mohsen, Development of SelfLeadership Skills Training Module Based on Need Assessment of Nursing Personnel: Mobile Learning Application, International Journal of Advanced Research in Management (IJARM), Volume 5, Issue 4, July-August (2014), pp. 66-84

[12] Ritzer, G. Sociology: A Multiple Paradigm Science (revised edition), Boston: Aliyn and Bacon, Inc. 1992, pp. 35

[13] M. Radhakrishnan, Dr. S. Sudha, an Overview of Employability Skills Required For Engineering College Leavers, International Journal of Management (IJM), Volume 3, Issue 1, January- April (2012), pp. 231-236

[14] Dr. B Nagaraju and Pooja J, Impact of Salary on Employee Performance Emperical Evidence from Public and Private Sector Banks of Karnataka. International Journal of Marketing and Human Resource Management, 8(4), 2017, pp. 43-51.

[15] Said Iqbal, Issue Perpres No. 20 of 2018 concerning Foreign Workers, Jokowi. Considered Panic. Submited by Editor on Sunday 8 April 2018, 00:48 
Analysis of Immigrant Labors Penetration in Indonesia in Industrial Sectors and Impact on the Existence of Indonesian Labors- A Study of Social Polarization Through the Theory of Interest Approach

[16] Sugiyono. Administrative Research Methods. Alfabeta, Bandung, 2010, pp 91

[17] Setiawan, B, \& Muntaha, A. Communication Research Methods. University Open Publishing Center, Jakarta. 2000, pp. 3.1

[18] Supranto, J. Sampling technique for surveys and experiments. Rineka Cipta. Jakarta.2000, pp 37

[19] Law No. 13 of 2003 concerning Employment of R.I. PT. Foyer of the Distribution Universe. Jakaarta

[20] Rajasekhar Devarapalli, Saroja Pilli, Prof. Vijayaratnam Naladi and Dr.Srinivasarao Pallekonda, an Empirical Study to Enhance the Knowledge and Skills through Training, International Journal of Management (IJM), Volume 6, Issue 1, January (2015), pp. 758-770

[21] Walpole, R.E. Introduction to Statistics. PT Gramedia Pustaka Utama Publisher, Jakarta. 1995, pp 207 